\title{
New World Slave Traders and the Problem of Trade Goods: Brazil, Barbados, Cuba, and North America in Comparative Perspective*
}

Historians of the transatlantic slave trade have long been aware of the high incidence of voyages originating in New World ports. Out of 35,938 voyages in the Transatlantic Slave Trade Database (now online as Voyages), 13,524 of them, or about 38 percent of the entire sample, embarked from New World, as contrasted with European ports (see figure 1). Accounting for the disproportionate number of Brazil-based voyages missing from the database would nudge that number higher, but let it suffice to say that New World-based traders accounted for a significant share of the total number of slaving voyages, probably approaching 40 percent. Although much of the data has been widely available in some form since 1999 (and although historians had been aware of New World-based slave trading for some time before that), the notion of a European-based and organised 'triangular trade' dominates the literature, to say nothing of the popular imagination. The major exception is the literature on Brazil and the South Atlantic, which has recently seen the publication of several excellent studies. The field at large, however, has been slow to incorporate their findings and has tended to maintain its North Atlantic focus. With no existing studies of New World slave trading in existence, this article will compare the larger powers of Cuba and Brazil, with the lesser powers, specifically Barbados and British North America, to explore the phenomenon in hemispheric perspective over two centuries. The focus will be on trade goods, although it is readily conceded that additional factors, such as merchant networks, wind patterns, and metropolitan commercial regulations also played important roles. ${ }^{1}$

\footnotetext{
*The author would like to acknowledge José Curto, Jeremy Krikler, Paul Lovejoy, Matthias Röhrig Assunção, and Suzanne Schwarz for their help and thoughts on this article.
} 


\section{[INSERT FIGURE 1 HERE]}

Despite a general awareness of New World-based slave trading, the phenomenon has not been explained, and there is much about it that needs explaining. Figure 1 suggests some of the reasons why historians have not tackled this particular issue. As the chart makes clear, American-based voyages - understood here as voyages originating in ports in the western hemisphere-surpassed European-based voyages by the $1820 \mathrm{~s}$ and accounted for an

\footnotetext{
${ }^{1}$ All slave trade statistics are taken from Voyages: The Transatlantic Slave Trade Database, version 3, online at www.slavevoyages.org. It bears reminding that Voyages contains two distinct sections. The first is the database of voyages for which evidence has been found. The second is the 'Estimates' section, which attempts to account for missing voyage data. For more on the difference, see D. Eltis and D. Richardson, 'Guide:
} Understanding and Using the Online Database and Website,' (2008). Major works on Brazil and/or the South Atlantic include F. Mauro, Le Portugal et L'Atlantique au XVIIe Siècle (1570-1670) (Paris, 1960); P. Verger, Trade Relations between the Bight of Benin and Bahia from the 17th to the 19th Century, trans. E. Crawford (Ibadan, 1976); J. C. Miller, Way of Death: Merchant Capitalism and the Angolan Slave Trade, 1730-1830 (Madison, WI, 1988); M. Florentino, Em Costas Negras: Uma História do Tráfico Atlântico de Escravos entre a Africa e o Rio De Janeiro (Séculos XVIII e XIX) (Rio de Janeiro, 1993); L. F. de Alencastro, O Trato dos Viventes: Formaçao do Brasil no Atlântico Sul, Séculos XVI e XVII (São Paulo, 2000); J. Rodrigues, De Costa a Costa: Escravos, Marinheiros, e Intermediários do Tráfico Negreiro de Angola ao Rio de Janeiro (17801860) (São Paolo, 2005); W. Hawthorne, From Africa to Brazil: Culture, Identity, and an Atlantic Slave Trade, 1600-1830 (Cambridge, 2010); R. Ferreira, Cross-Cultural Exchange in the Atlantic World: Angola and Brazil in the Era of the Slave Trade (Cambridge, 2012); M. P. Candido, An African Slaving Port and the Atlantic World: Benguela and Its Hinterland (Cambridge, 2013); D. Richardson and F. Ribeiro da Silva, eds., Networks and Trans-Cultural Exchange: Slave Trading in the South Atlantic, 1590-1867 (Leiden, 2015); D. B. Domingues da Silva, The Atlantic Slave Trade from West Central Africa, 1780-1867 (Cambridge, 2017). Cultural links, especially between Bahia and the Bight of Benin, have received somewhat more attention. Recent explorations include K. Mann and E. G. Bay, eds., Rethinking the African Diaspora: The Making of a Black Atlantic World in the Bight of Benin and Brazil (London, 2001); L. Matory, Black Atlantic Religion: Tradition, Transnationalism, and Matriarchy in the Afro-Brazilian Candomble (Princeton, 2005); N. Parés, The Formation of Candomblé: Vodun History and Ritual in Brazil (Chapel Hill, 2013). 
increasing share of the traffic until the effective end of the transatlantic slave trade in the 1860s. It is a matter of arithmetic that the percentage increase in the New World share of slave trading voyages rose greatly with the post-abolition withdrawal of the European slave trading powers from the practice of outfitting voyages. The explanation seems equally obvious: New World-based slavers entered the trade in order to compensate for the withdrawal of metropolitan suppliers. Though not incorrect, the very obviousness of that conclusion has prevented historians from investigating more difficult questions. Specifically, if abolition were the spur for American involvement, then how do we explain the prevalence of New World-based trading in the seventeenth and eighteenth centuries-that is, before abolition--in Barbados, Brazil, and British North America? For a century or more, these powers did not so much replace metropolitan slave traders as compete with them. Of the major New World slave trading powers, Cuba is the only one that began outfitting voyages in significant numbers in the wake of abolition. ${ }^{2}$

The focus on why merchants in the Americas got into the trade has overshadowed a much more difficult question: how did New World residents manage to participate? After all, slaving voyages were not easy to organise. One of the most difficult challenges was to find the right trade goods, and many a trader discovered that Africans were neither naïve nor passive consumers. A full discussion of African consumption during the era of the slave trade is beyond the scope of this piece, but there is now a clear consensus that that Africans were consistently discriminating in their tastes. Demand for goods was highly particular, both in

\footnotetext{
${ }^{2}$ Spain allowed its subjects to engage in slave trading beginning in 1789 , but Britain and the United States supplied Cuba with most of its captives before 1808. On the evolution of Spanish policy, see J. L. Franco, Comercio Clandestino de Esclavos (Havana, 1980), 93-101. On the New World-based trade as a response to the withdrawal of European-based traders, see D. Eltis, Economic Growth and the Ending of the Transatlantic Slave Trade (New York, 1987), 47; M. Zeuske, Amistad: A Hidden Network of Slavers and Merchants, trans. Steven Rendall (Princeton, 2015), 83.
} 
regard to the type of good (textiles, spirits, guns) and the specific qualities within a category of goods (weaves, patterns, and colors of textiles, for example). Tastes varied greatly from region to region and could change suddenly within a given region, to the endless frustration of coastal factors. To further complicate European traders' lives, exchange was almost never conducted on the basis of a single good. Instead, African merchants usually demanded what the British called an 'assortment' of goods, which meant a particular combination of textiles and manufactures, along with spirits and other items. Though subject to negotiation, the precise assortment was fairly stable in most areas, at least in the short term. The goal of any slaver was to minimise the 'prime cost' of the trade goods while coming as close as possible to the preferred regional assortment. Vessels arriving without the preferred regional assortment would find their goods devalued and their purchasing power diminished. ${ }^{3}$

\footnotetext{
${ }^{3}$ Major works on consumption of European and Asian goods in pre-colonial Africa during the era of the transatlantic slave trade include M. Johnson, 'The Ounce in Eighteenth-Century West African Trade', Journal of African History, vii , (1966), pp. 197-214; Verger, Trade Relations; D. Richardson, 'West African Consumption Patterns and Their Influence on the Eighteenth-Century English Slave Trade', in H. A Gemery and J. S. Hogendorn, ed., The Uncommon Market: Essays in the Economic History of the Atlantic Slave Trade, (New York, 1979); G. Metcalf, 'A Microcosm of Why Africans Sold Slaves: Akan Consumption Patterns in the 1770s', Journal of African History, xxviii (1987), pp. 377-394; R. Roberts, 'West Africa and the Pondicherry Textile Industry', Indian Economic and Social History Review, xxxi (1994), pp. 117-145; S. B. Alpern, 'What Africans Got for Their Slaves: A Master List of European Trade Goods', History in Africa, xxii (1995), pp. 543; E. K. Akyeampong, Drink, Power, and Cultural Change: A Social History of Alcohol in Ghana, C. 1800 to Recent Times (Portsmouth, N.H, 1996); J. C. Curto, Enslaving Spirits: The Portuguese-Brazilian Alcohol Trade at Luanda and Its Hinterland, C. 1550-1830 (Boston, 2004); C. E. Kriger, Cloth in West African History (Lanham, MD, 2006); C. E. Kriger, "'Guinea Cloth": Production and Consumption of Cotton Textiles in West Africa before and During the Atlantic Slave Trade', in G. Riello and P. Parthasarathi, ed., The Spinning World: A Global History of Cotton Textiles, 1200-1850 (Oxford, 2009); K. Kobayashi, 'Indian Cotton Textiles and the Senegal River Valley in a Globalising World: Production, Trade, and Consumption, 1750-1850', Ph.D. thesis, London School of Economics, 2016.
} 
Since textiles and manufactured goods enjoyed the highest demand along the African coast (one prominent historian estimates that textiles financed at least 50 percent of the cost of all Africans carried to the New World, approaching two-thirds in many regions), New World-based traders were at a great disadvantage in comparison with metropolitan traders. One option for them, of course, was to find markets where New World-produced goods were in demand. The other was to acquire textiles and manufactures from abroad and re-export them to Africa, but this obviously would drive up costs. As it happened, merchants in several regions of the Americas devised strategies that allowed them to compete with metropolitan merchants in the slave trade. This competition, moreover, has significance for the eventual post-abolition surge in New World-based trading. The fact that they had solved the problem of trade goods, in most cases before the advent of abolition, meant that those plantation societies that chose to could continue to supply themselves with captives even after the withdrawal of metropolitan suppliers. Trade goods, then, held the key to New World-based slave trading. Without them, colonial merchants would have found it impossible to engage in the slave trade. ${ }^{4}$

A comparative analysis of the trade goods employed by American-based slave traders promises to shed light on the question. Trade goods, while certainly not the only factor that explains the New World-based slave trade, were nevertheless essential to its functioning. Mercantilist regulations, wind patterns, and merchant networks all played important roles, but trade simply could not have proceeded without goods that enjoyed some kind of demand in Africa. A comparative analysis is especially useful given the geographic and temporal sprawl of New World-based slave trading, with four American regions participating over more than two centuries. Though the most of this trading was undertaken by Brazil and Cuba, we can

\footnotetext{
${ }^{4}$ H. S. Klein, The Atlantic Slave Trade (Cambridge, 1999), p. 87. See also D. Eltis, The Rise of African Slavery in the Americas (Cambridge, 2000), pp. 168, 176.
} 
learn a great deal by considering them alongside smaller players, like North America and Barbados. New World-based trading was likewise concentrated in the nineteenth century (as a result of Brazilian and Cuban dominance), but examining these trades in earlier time periods provides valuable perspective on how things changed over time and serves as a reminder that networks and practices built in the seventeenth and eighteenth centuries helped to lay the groundwork for the later New World-based illegal trade.

Given the disparate and varied nature of the regions under examination, the documents that reveal which trade goods were used inevitably differ. For Cuba and Brazil, the records of the Court of Mixed Commission at Sierra Leone furnish a very detailed sample of the trade goods carried in the nineteenth century. There is much less available for earlier Brazilian voyages - to date much of the information still rests in the archives--but information on outbound cargoes from Bahia in the late seventeenth and early eighteenth centuries can be found in the legal records of goods carried on consignment, which have been published. For New England, trade books, or records of those goods exchanged for captives, were particularly useful and detailed. About a dozen trade books survive, but only for the pre-1776 period. For the later era, over 130 ships' manifests were consulted, covering the years 1790 1801. For Barbados, most of what we know comes from the port records of the CO 33 series in the British National Archives, which provides information on 116 individual outbound cargoes from 1698-1720.

This diversity of sources complicates the task of comparison; our knowledge of which goods were in play at various times and places is uneven, making reliable quantification impossible. But taken together, the comparison demonstrates that all four of the major American slave trading participants-Barbados, Brazil, British North America/United States, and Cuba — managed to solve the problem of trade goods, though each in a slightly different way. The ability to convert New World produce into commodities in demand on the African 
coast was central to all of these trades. Not surprisingly, distilled cane sugar byproducts figured in all four trades: rum in the case of Barbados and North America, cachaça (also known as gerebita) in the case of Brazil, and aguardiente in the case of Cuba. Tobacco featured to some extent in all but the Barbados-based trade, and for a time gold provided a boost to the Brazilian trade. To this, North America and Brazil, as non-insular powers, were able to add smaller quantities of livestock, food products, and manufactures. But perhaps the most surprising aspect of these trades was the frequency of textiles, of European, Asian, and African origin, in the trades of all four New World slaving polities. The type, provenance, proportionate value of the textiles for American-based traders varied from place to place and over time, but with few exceptions they were always a factor.

The latter finding is quite significant and suggests three things. First, it underscores the difficulty_perhaps even the impossibility--of operating a slave trade on the basis of one, or even two agricultural commodities or byproducts. In this respect, American-based traders had to play by the same rules as metropolitan traders by 'assorting' their cargoes to cater to African demand to maximise their return on investment. Second, the presence of textiles and other European and Asian manufactures in the holds of New World-based slave ships highlights the essentially colonial economic status of the American colonies, and even (in the case of the United States and post-1822 Brazil) of independent polities. ${ }^{5}$ Most of these powers could not base their slave trade on plantation produce alone, at least over the long term. The New England 'rum men' of the eighteenth century came the closest to succeeding on alcohol and tobacco alone, but even they looked to 'sort' their cargoes with textiles and manufactures that had to be obtained from elsewhere, either before embarkation or while on

\footnotetext{
${ }^{5}$ On the peripheral nature of the slave trade in the Portuguese Empire, see J. C. Miller, 'A Marginal Institution on the Margin of the Atlantic System: The Portuguese Southern Atlantic Trade in the Eighteenth Century', in B. L. Solow, ed., Slavery and the Rise of the Atlantic System (Cambridge, 1991), pp. 120-150.
} 
the African coast. Finally, the sorting of cargoes reveals the degree to which slavers, whether based in the Americas or Europe, operated not merely within a North or South Atlantic System, but rather functioned as nodes in a truly global system of trade.

The present discussion will proceed by examining the four largest New World-based slave trading powers in rough chronological order according to when they first began their regularised activities. Brazil, which began a sustained bilateral trade sometime in the seventeenth century, will be the first case. The British West Indies, led by Barbados, which inaugurated a modest bilateral trade starting in the late seventeenth century, will be the second example, followed by an examination of the North American traders, most of whom were based in New England and New York. Cuba, the final case, was a latecomer to the trade, sending out some vessels at the end of the eighteenth century but beginning in earnest only in the early nineteenth century after the withdrawal of Britain and the United States. Throughout, the focus will be on trade goods, on 'following the money' as it were, which involves addressing two questions to each of these cases: what trade goods were used to purchase captives, and where did those trade goods come from?

[SINGLE LINE SPACE HERE]

\section{I}

In the earliest years of the Atlantic slave trade, before about 1500, the classic triangular voyage did not exist. The first voyages were in essence bilateral and cis-Atlantic, as Portuguese vessels sailed from Lisbon to various points on the African coast and shipped their captives back to Portugal. Even after 1492, the first transatlantic voyages were still usually bilateral. Columbus' shipments of Taino and Carib captives from Hispaniola to Spain in 1493 and the first documented shipment of African labourers from Spain to Hispaniola in 1501 were both bilateral, though they moved in opposite directions. Nor did the first trilateral voyages, such as those that left from São Tomé, embarked captives in West Central 
Africa, and carried them to the Gold Coast or the Atlantic islands, conform to the classic triangular pattern of later centuries. Europeans had been conducting this cis-Atlantic slave trade for seven decades before the first recorded transatlantic 'triangular' voyage was completed, in 1525 by the Lisbon-based S. Maria de Bogonã, which carried captives from São Tomé to Hispaniola. It was only then that the classic triangular pattern, in which the vessel embarked from a European port, purchased captives in an African port, and delivered them to an American port, began to emerge. Even so, merchants continued to organise bilateral voyages of many descriptions, some dispatched from the Americas to Africa and back, some organised in Africa for the New World and back, and some organised in one part of Africa for another. These voyages were few, however, which suggests that they were improvised, speculative ventures, or perhaps a onetime deal between mercantile correspondents in two locations. ${ }^{6}$

Like so much in the history of Atlantic slavery, the story of New World-based slave trading really begins with Brazil, the largest American power to conduct a regular trade in captives. Portugal, of course, continued to dispatch vessels throughout its long history of involvement in the slave trade, but most of the vessels listed in the Voyages database as

\footnotetext{
${ }^{6}$ A. de Almeida Mendes, 'The Foundations of the System: A Reassessment of the Slave Trade to the Spanish Americas in the Sixteenth and Seventeenth Centuries', in D. Eltis and D. Richardson, ed., Extending the Frontiers: Essays on the New Transatlantic Slave Trade Database (New Haven, 2008), pp. 63-67. See also H. Thomas, The Slave Trade: The Story of the Atlantic Slave Trade, 1440-1870 (New York, 1999), pp. 68-113. For the 1525 voyage, see Voyages, \#46473. For some of the patterns and routes of the early cis-Atlantic trade, see D. Eltis and D. Richardson, Atlas of the Transatlantic Slave Trade (New Haven, 2010), p. 7. On the role of Cape Verde in the early Atlantic slave trade, see T. Green, The Rise of the Trans-Atlantic Slave Trade in Western Africa, 1300-1589 (Cambridge, 2012).
} 
'Portuguese' actually saw their voyages originate in Brazil. ${ }^{7}$ The Brazil-based trade was complex, varying greatly across time and space. Although each of the three major slavetrading regions-Pernambuco, Bahia, and Rio de Janeiro—operated very differently and will be explored in turn momentarily, they shared several important features. First, all of them drew upon a broadly similar assortment of trade goods. These included plantation produce and byproducts, with cachaça and tobacco constituting the most significant. These good differed from the assortments carried by Lisbon-based vessels, which carried more textiles and manufactures, less alcohol (with wine far more important than distilled spirits), and very little tobacco. But re-exported manufactures were also present on most Brazilian vessels. Before the nineteenth century, Indian textiles were the most significant re-exported trade good, but Portugal's post-1807 transformation into a British political and economic client (much of which persisted after Brazilian independence) meant that much of the cloth used in later years originated in the mills of Lancashire. Brazilian vessels also carried much smaller quantities of European manufactures, ranging from guns and knives to luxury items, such as silk stockings, ribbons, and glassware. These re-exports allowed Brazilians maximise the value of their plantation goods by 'sorting' them (as the British would have said) into more optimal combinations calculated to appeal to local African tastes. ${ }^{8}$

[INSERT FIGURE 2 HERE]

\footnotetext{
${ }^{7}$ Determining whether a given vessel or voyage was, in some definitive sense 'Portuguese' or 'Brazilian' is difficult—see the discussion of merchant networks below. However, in the Voyages database about 86 percent of all Portuguese/Brazilian-flagged vessels began their voyages in Brazil, while about 11 percent originated in Europe. See Voyages, http://www.slavevoyages.org/voyages/bS6B1Z0H.

${ }^{8}$ For silk stockings, ribbons, and glassware aboard Brazilian vessels, see A. A. Viera Nascimento, "Letras de Risco" e "Carragaçoes" no Comércio Colonial de Bahia, 1660-1730 (Salvador, 1977), p. 20. For outbound cargoes form Portugal, see L. A. Newson and S. Minchin, From Capture to Sale: The Portuguese Slave Trade to Spanish America in the Early Seventeenth Century (Leiden, 2007), p. 47.
} 
The diffuse structure and financial practices of the Portuguese mercantile community gave Brazilian merchants (or in most cases, Portuguese merchants resident in Brazil) several additional ways to offset the disadvantages of trading in tobacco and liquor. To a much greater extent than any of the other New World slave-trading powers, the Brazilian slave trade was organised in Brazil. However, it was undertaken by networks of merchants who cannot be said to be wholly 'Portuguese' or 'Brazilian'. As Daviken Studnicki-Gizbert has demonstrated, rather creating a radial system centered on a European metropolis, Lusophone merchants constructed a vast and intricate system of interconnected hub-and-spoke networks. This decentralised nodal system meant that individual Brazilian vessels did not need to finance an entire shipment of captives with trade goods alone. Brazilian vessels often carried letters of credit and bills of exchange on Lisbon and other nodes of Portugal's far-flung trading empire. Especially prominent were 'letters of risk,' in which a merchant in one location-in Brazil, for present purposes--would lend money to a partner or client, who would carry to the letter to a second location-e.g. Luanda--and use it to purchase trade goods or captives. Capital accumulated in one locale could thus be used to help 'sort' a cargo of trade goods. Part of the answer, then, to the question of how the Brazilians managed to engage in the slave trade lies in the diffuse nature of Portuguese merchant networks and the degree to which they facilitated the circulation of bills of exchange and letters of credit. ${ }^{9}$

\footnotetext{
${ }^{9}$ D. Studnicki-Gizbert, A Nation Upon the Ocean Sea: Portugal's Atlantic Diaspora and the Crisis of the Spanish Empire, 1492-1640 (Baltimore, 2007), pp. 94-96, 100-107, 119-121. On the use of letters of credit and bills of exchange in the later Brazil-Angola trade, see Viera Nascimento, "Letras de Risco", p. 10-12; J. C. Miller, 'Capitalism and Slaving: The Financial and Commercial Organization of the Angolan Slave Trade, According to the Accounts of Antonio Coelho Guerreiro (1684-1692)', International Journal of African Historical Studies, xvii (1984), p. 8. Of course, trade goods and captives did not correspond perfectly in North Atlantic trading; slave trading merchants could and did carry balances to be reconciled in the future. Vessels with common ownership also transferred goods and captives amongst themselves, and traders employed
} 
Finally, the system of trade at Angola, a destination for vessels from all three Brazilian regions, was structured in a way that helped New World-based merchants to circumvent the problem of trade goods. There, much of the trade was channeled through the governor at Luanda, who administered the royal monopoly by selling licenses to transport slaves. Governors usually partnered with metropolitan merchants to finance their own ventures, but they also sought to avoid shouldering the risks associated with the slave trade. Legal ownership of the captives was often retained by Angola-based merchants, who shipped them as freight, until their sale in Brazil (although this became less common as the eighteenth century progressed). Many Brazilian shippers were therefore not slave traders in the same sense as their North Atlantic counterparts, but rather ship owners looking to sell cargo space. They delivered their cachaça, tobacco, and textiles-often on consignment--to Angola-based merchants. Angolan merchants accumulated Brazilian cachaça and tobacco, along with the textiles that arrived via Brazil, Asia, Portugal, and other nodes of the Portuguese Atlantic and Indian Ocean systems. They then re-packaged the goods into appropriate assortments and forwarded them to their correspondents in the Angolan sertão to purchase captives. The agents in turn used the goods to finance their captive purchases. The one-to-one correspondence between the value of the trade goods aboard a given vessel and captives it carried, so characteristic of North Atlantic slaving, did not prevail in the South Atlantic. In fact, given the structure of the system, it can be difficult to say whether a given voyage 'originated' in Brazil or in Angola - the notion of voyage origin or organization as understood in the North Atlantic triangular trade fails to capture the essential process. But the system allowed Brazilians to trade profitably using cachaça and tobacco not only because

financial instruments like bills of exchange to balance the books. Nevertheless, the general expectation in the North Atlantic was that a vessel would finance the purchase of captives with its own trade goods. 
they sorted their outbound cargoes with textiles but because a second sorting process took place in the warehouses of Luanda and Benguela. ${ }^{10}$

[SINGLE LINE SPACE HERE]

\section{II}

Of the three regional Brazilian trades, Pernambuco's was the first to develop. Major gaps in shipping and other records have made it difficult to reconstruct the Pernambuco trade, but the basic outline is clear. Pernambuco was the hemisphere's first major sugar-planting colony and began its shift from indigenous American to imported African labor in the second half of the sixteenth century, with the transition more or less complete in the early seventeenth century. Although Pernambuco was soon overtaken as a sugar producer by Bahia and later by the West Indies, cane continued to dominate the region for the next 250 years, with tobacco furnishing a secondary export. Pernambuco only stopped importing enslaved laborers after 1850, along with the rest of Brazil. By that time some 800,000 captives had been disembarked in the captaincy/state. Over its years of involvement in the slave trade, Pernambuco traded for captives in all parts of Africa, with West Central Africa as the dominant supplier. This pattern was broken during the Dutch occupation of 1630-1654 and during the gold cycle of the early eighteenth-century, which in both cases produced an influx of captives from Lower Guinea. Whatever their African destinations, about 82 percent

\footnotetext{
${ }^{10}$ D. B. Domingues da Silva, 'The Supply of Slaves from Luanda, 1768-1806: Records of Anselmo da Fonseca Coutinho', African Economic History, xxxviii (2010), p. 64; D. B. Domingues da Silva, The Atlantic Slave Trade form West Central Africa, p. 129.
} 
of all voyages carrying captives to Pernambuco originated there. An additional ten percent sailed from other Brazilian ports, so this was overwhelmingly a New World-based trade. ${ }^{11}$

Little work has been done on the organization of the Pernambuco slave trade, so a rudimentary outline is all that is possible. Like virtually all Brazilian vessels, Pernambuco's slavers carried cachaça and tobacco, in effect recirculating their plantation surplus to purchase more labor. However, it is unlikely that the earliest voyages carried these goods. Brazilians did not master the art of distilling until the mid-seventeenth century, so rather than cachaça, the earliest vessels may have carried fermented cane beverages, or they may have re-exported Portuguese wine. Once the trade matured, cachaça would have eclipsed all other types of alcohol. Pernambuco vessels also sailed with tobacco, but the local variety was never as popular or valuable as the Bahia product, which relegated it to secondary status behind cachaça. And as will be seen in the case of Bahia, the tobacco trade took time to develop, maturing only in the eighteenth century. ${ }^{12}$ In all probability Pernambuco vessels also carried Indian textiles, along with lesser amounts of local produce to supply the 'Portuguese' communities on the African coast. Portuguese vessels sailing to and from India frequently stopped in Bahia, and it is likely that Pernambuco merchants managed to secure at least some textiles via coastwise trade. Re-exporting cloth to Africa entailed higher costs, but evidence from later years shows that it was routine to do so, and it is worth keeping in mind that the earliest years of the slave trade coincided with the height of Portugual's Asian

\footnotetext{
${ }^{11}$ D. B. Domingues da Silva and D. Eltis, 'The Slave Trade to Pernambuco, 1561-1851', p. 117, in Eltis and Richardson, Extending the Frontiers. On the Dutch in Brazil, see M. van Groesen, Amsterdam's Atlantic: Print Culture in the Making of Dutch Brazil (Philadelphia, 2017).

12 Curto, Enslaving Spirits, pp. 47-48, 69. On fermented cane juice in the Caribbean, see F. H. Smith, Caribbean Rum: A Social and Economic History (Gainesville, FL, 2005), pp. 12-15.
} 
empire. It is also worth remembering that the structure of the Portuguese empire and the system at Angola also would have helped the cause of the early Pernambuco traders. ${ }^{13}$

By the mid-seventeenth century, Pernambuco merchants were using a combination of cachaça and tobacco as trade goods, supplemented by financial instruments, mostly with Angola. While many factors explain the strong historic connection between Pernambuco and Luanda, surely one of the most important is the simple fact that the latter was Africa's strongest cachaça market. Alcohol and distilled spirits in general were very popular throughout most of Atlantic Africa during the era of the slave trade. But African consumers did not drink alcohol in general; they preferred specific types of beverages. How these tastes developed is beyond the scope of the present discussion, but given the strong links between alcohol and ritual, in Africa as elsewhere, it is safe to assume that once accepted, a particular type of drink remained popular simply out of force-of-habit. This same dynamic of taste helps to explain why Pernambuco sent a disproportionate share of its vessels to Angola; it was the only place where cachaça enjoyed a strong market. Different spirits commanded the tastes of consumers elsewhere in Atlantic Africa. West Indian and North American rum was the favored spirit along the Gold Coast. On the Bight of Benin, an important destination for Brazilian traders, the preferred spirit was French brandy. Pernambuco vessels did carry cachaça, to West Africa, but it could only serve as a second-choice substitute for the preferred product. Similarly, Angola was the only place where Pernambuco tobacco found a market, though it was a weak one. ${ }^{14}$

\section{[SINGLE LINE SPACE HERE]}

\footnotetext{
${ }^{13}$ R. Ferreira, 'Transforming Atlantic Slaving: Trade, Warfare, and Territorial Control in Angola' (Ph.D. Diss., UCLA, 2003), pp. 56-57.

${ }^{14}$ Curto, Enslaving Spirits, pp. 32-35, 50-51, 69. On alcohol in Ghana, see Akyeampong, Drink, Power, and Cultural Change, pp. 21, 30. For a deliberate attempt by merchants to establish a taste for a specific type of alcohol, see TNA, T 70/22, pg. 15, and the Barbados discussion below.
} 


\section{III}

As a sugar captaincy, Bahia was in many respects similar to Pernambuco, but its slavetrading profile was quite different. West Central Africa was the destination two-thirds of Pernambuco's vessels, while the Bight of Benin ran a distant second at fifteen percent. Bahia, on the other hand, sent approximately 55 percent of its vessels to the Bight of Benin, with only 32 percent clearing for Angola. The cause of this pattern is well known to historians: consumers in Lower Guinea preferred Bahian tobacco over all other varieties. Though of refuse grade by European and Brazilian tastes and barred from metropolitan markets, when cured in molasses the Bahian product struck just the right note with consumers from the Gold Coast to the Gulf of Guinea. The first evidence of the trade dates to the 1640s, when the Dutch, looking to improve their assortment of goods, allowed Brazilian vessels to trade in tobacco at the former Portuguese castle of São Jorge da Mina, which was closely followed by a Portuguese decree allowing Bahian merchants to trade directly with the Bight of Benin. But though Bahian traders may already have been shipping tobacco when these decrees were issued, it took time for the trade to mature. It was only in the early eighteenth century that Bahian tobacco was firmly established in the region as an essential trade good. During the Brazilian mining boom of the early eighteenth century, some Bahian traders were able to supplement their outbound cargoes with gold from Minas Gerais, obtained by the sale of captives to the Mineiros. By 1750, however, Brazilian gold production had begun to decline, which resulted in a corresponding decline in the amount brought to the Bight of Benin. By 1776, Brazilian gold had disappeared as a trade good at Ouidah. ${ }^{15}$

\footnotetext{
${ }^{15}$ Verger, Trade Relations, pp. 12-13. Robin Law has questioned Verger's assertion that Bahian tobacco was firmly established as a trade good during the mid-seventeenth century. See R. Law, The Slave Coast of West Africa, 1550-1750 (Oxford, 1991), pp. 123, 134-136; R. Law, 'The Gold Trade of Whydah in the Seventeenth and Eighteenth Centuries', in D. Henige and T. C. McCaskie, ed., West African Economic and Social History (Madison, WI, 1990), pp. 110-111.
} 
The connections between Bahia and the Bight of Benin have received a great deal of attention, thanks largely to the pioneering work of Pierre Verger. But it is perhaps testament to the force of his work that it has obscured almost as much as it has illuminated about this historic axis. First, as the Voyages database has made abundantly clear, the 'Mina Coast' was not Bahia's sole source of captives, accounting for just over half. In fact, during the seventeenth century, before the emergence of tobacco as a major trade good, Bahian vessels traded mostly in Angola, alongside Pernambuco vessels. But important for the sake of this discussion is Verger's suggestion that the Baianos financed their entire trade with tobacco. As has been noted, it was rarely possible to engage in the transatlantic slave trade on any sustained or significant scale on the basis of a single commodity. ${ }^{16}$

Verger's conclusion that tobacco was the sole commodity carried aboard Bahian vessels was apparently based on statements made by northern European company employees and traders on the African coast. During the eighteenth century, many of these traders were being squeezed out of the market for captives by the combination of Brazilian gold and tobacco, and their reports reflect as much. But a different picture of the Bahian trade emerges when we look at what their vessels actually carried. Although manifests are scarce, we can get a sense of the basic mix of trade goods carried aboard early Bahian vessels thanks to the work of Anna Amelia Viera Nascimento, who examined the carregações (goods carried on consignment) for fourteen Bahia-Africa voyages undertaken between 1667 and 1733. These carregações do not represent complete cargoes and cannot be taken as an unbiased sample. By their nature, they represented smaller ventures entrusted by residents of Bahia to agents for sale in Africa. Indeed, the relative insignificance of tobacco speaks to their probable

\footnotetext{
${ }^{16}$ See, for example, A. Viera Ribeiro, 'The Transatlantic Slave Trade to Bahia, 1582-1851', p. 142, in Eltis and Richardson, Extending the Frontiers, which acknowledges the use of gold dust and rum but does not mention textiles.
} 
unrepresentativeness. Still, what is most striking about them is the diversity of goods carried, to the extent that it is difficult to delineate any single pattern or norm. Of the eight surviving contracts for Lower Guinea (the other six were for Angola) dating to the early eighteenth century, only two involved tobacco. The most frequently mentioned good was textiles, which was present in five of eight cargoes. Only a single vessel carried aguardente (for our purposes analogous to cachaça), while three others carried various other goods, including iron, sugar, and lesser manufactures. Although the contracts do not allow for the calculation of the relative value of these commodities, it is virtually certain that textiles far outstripped all other goods in their total worth. It bears repeating that these contracts are not necessarily representative of all Bahian vessels. It may be that goods other than tobacco were more likely to reach Africa by consignment. Nevertheless, they demonstrate quite clearly that the Bahians purchased their captives with a wider variety of goods than is generally assumed. ${ }^{17}$

\section{[INSERT TABLE 1 HERE]}

Nor was this pattern limited to the eighteenth century. In 1815 Britain forced Portugal to agree to a ban on slave trading north of the equator, which in theory would have ended the Bahian trade at the Bight of Benin. That trade continued, but its illegality actually allows for a more precise and quantifiable portrait of the Bahian trade goods. An analysis of the goods carried aboard eight Bahian vessels captured by the Royal Navy while slaving in Lower Guinea in 1826-1828 provides an idea of the goods used in the trade. Once again, most

\footnotetext{
${ }^{17}$ Viera Nascimento, "Letras de Risco," 21-23, 33-40. Seven of eight consignments were for "Costa da Mina;" one was for "Benin.” See also C. F. da Silva Júnior, ‘Tráfico, Escravidão e Comércio em Salvador do Século XVIII: a Vida de Francisco Gonçalves Dantas', in J. J. Reis and E. Azevedo, ed., Escravidão e Suas Sombras, ed. (Salvador, 2012), pp. 171-172; M. E. Hicks, 'Financing the Luso-African Slave Trade, 1500-1840: Collective Investment Practices from Portugal to Brazil', Journal of Global Slavery, ii (2017), pp. 273-309. Manolo Florentino has registered doubt over whether the entire Bahian trade was conducted with tobacco. See Florentino, Em Costas Negras, 124.
} 
striking is the prominence of textiles, which accounted for almost half of the value of the vessels' trade goods. Spirits, listed in most cases as 'aguardiente,' accounted for forty percent of the value. Tobacco accounted for only nine percent of the value of the cargoes seized from these vessels. As with the consignment contracts from the eighteenth century, these cargoes may not be perfectly representative. In several cases, it appears that the vessels had already landed some of their trade goods, which means that only part of the cargo was aboard the vessel when seized. But the general pattern is quite clear and consistent with the consignment contract data from the previous century. It is also well worth remembering that the Bahians, like all of the Portuguese/Brazilian merchants, used letters of risk and other instruments of credit to finance their dealings. The Bahian slave trade, then, was not conducted solely on the basis of tobacco; textiles, spirits and credit all allowed for the diversification of cargoes. ${ }^{18}$

[INSERT FIGURE 3 HERE]

[SINGLE LINE SPACE HERE]

\section{IV}

Rio de Janeiro only began its sustained involvement in the slave trade after Pernambuco and Bahia. Sugar planting took hold in Rio's hinterland in the early eighteenth century. But

\footnotetext{
${ }^{18}$ See sources for Figure 2. It is worth noting that many of the vessels condemned by the Court at Sierra Leone had already purchased captives and so furnish no evidence for trade goods. Others had sent some of their goods ashore before being seized, therefore the remaining goods may not have been representative. Based on an analysis of similar sources, David Eltis has reached a different conclusion, arguing that tobacco comprised between 80 and 90 percent of the outbound cargoes of Bahian slave ships. The estimate, however, appears to be based on the quantity or volume of the commodities taken off the vessels at Sierra Leone, multiplied by the value of the commodities as given in the Rio mercantile press. The values used in Figure 2 are based on the auction price at Sierra Leone. See D. Eltis, 'The British Contribution to the Nineteenth-Century Transatlantic Slave Trade', Economic History Review, xxxii (1979). Pp. 217-218.
} 
it was the gold rush in Minas Gerais, which began in approximately 1690 and lasted until about 1750 , that provided the strongest spur. Rio did not have a monopoly on supplying captives to Minas-Bahia also supplied them—but geographically it was in the best position and so took advantage to dominate that market. Carioca merchants continued their involvement in the transatlantic slave trade as coffee planting spread throughout southern Brazil in the late eighteenth and early nineteenth centuries. The opening of Brazilian ports to international trade after 1811 resulted in a sharp increase in trafficking that only ceased after 1850 , by which time Rio was the point of entry for 70-90 percent of all Africans carried to Brazil. This late burst of activity made Rio the hemisphere's leading entrepot for enslaved labor, the point of disembarkation for one-fifth of all Africans carried to the Americas. Not surprisingly then, Rio has generated a sizable and high-quality literature. As with Pernambuco and Bahia, Rio's was a bilateral trade. The city's connection to Africa is fairly easily summarised: West Central Africa, specifically Luanda and Benguela, was the destination of roughly three-quarters of Rio's slave ships. Southeast Africa was the secondleading market for city's slave merchants, but since it accounted for only about fifteen percent of all voyages, the focus here will be on Angola. ${ }^{19}$

The structure of Rio's Angola trade was similar to that of the other Brazilian regions. Elite merchants traded on their own accounts, but many others were essentially exporters and ship owners who charged freight on the captives sent back to Brazil. Ownership of the captives often remained with the Angola-based shippers, who paid for them with an assortment of goods imported not only from Brazil, but from India, Portugal, and the rest of Europe. However, just as Rio's merchants were increasing their involvement in the slave

\footnotetext{
${ }^{19}$ M. Florentino, 'The Slave Trade, Colonial Markets, and Slave Families in Rio De Janeiro, Brazil, Ca., 17901830', pp. 280-281, in Eltis and Richardson, Extending the Frontiers. For an overview, see Florentino, Em Costas Negras; Rodrigues, De Costa a Costa.
} 
trade, two other developments strengthened their position. The first was the growth of the British textile industry. British cloth had made up a portion of the textiles used in the Brazilian slave trade since the seventeenth century, but with industrialization starting at the end of the eighteenth century, Britain was well on its way to displacing India as the world's leading producer. By the early nineteenth century, British textiles rivaled Indian cloth as trade goods aboard Rio's slave ships. The flight of the Portuguese court to Rio in 1807, which made that city the center of the empire, speeded the process. Britain, which orchestrated the move, required Portugal to open its markets. Though the flood of imports did damage to other sectors of the Brazilian economy, the greater availability and lower prices for textiles lowered the costs of the city's traders. Sold by on credit by British merchants to Rio's slave traders, it appears that British textiles and other goods accounted for about half of the value of the trade goods that financed the importation of enslaved Africans. $^{20}$

Shipping reports in Rio's Jornal do Comércio, analyzed by Manolo Florentino, furnish us with a sense of the trade good assortment carried aboard vessels of the early nineteenth century, though unfortunately they did not always report values. Spirits led all other goods in frequency, with 94 percent of all vessels reporting it in the outbound cargo. Textiles were

\footnotetext{
${ }^{20}$ Eltis, "The British Contribution to the Nineteenth-Century Transatlantic Slave Trade," 219-220; Domingues da Silva, The Atlantic Slave Trade from West Central Africa, 40, 130-131. Giorgio Riello gives the 1810s as the decade during which Britain surpassed India as the world's leading producer of cotton textiles. See G. Riello, 'The Indian Apprenticeship: The Trade of Indian Textiles and the Making of European Cottons', p. 309, in G. Riello and T. Roy, ed., When India Clothed the World: The World of Indian Textiles, 1500-1850, ed. (Leiden, 2009). Colleen Kriger has proposed an earlier time frame, at least from the African consumer's perspective, with British goods constituting 70-80 percent of imports by 1800. See Kriger, "'Guinea Cloth", 123. See also J. E. Inikori, 'English versus Indian Cotton Textiles: The Impact of Imports on Cotton Textile Production in West Africa,' pp. 85-114, in Riello and Roy., ed., When India Clothed the World.
} 
present on 86 percent of all vessels, gunpowder or weapons were aboard 80 percent, tobacco on 52 percent, with wire and silver accounting for much lower proportions. In his analysis of cargoes from the years 1827-1830, Florentino found that only 14 percent of the vessels sailed with agricultural produce and byproducts alone; the remainder carried re-exported manufactures. Yet another analysis covering 1811-1813, years for which values are available, revealed that textiles were the most valuable trade good, accounting for between 67.8 and 89.7 percent of the goods traded for captives at Benguela and 68 percent and 79 percent of the goods traded at Luanda. In all, it appears that approximately two-thirds of all Indian textiles arriving in Rio during these years were re-exported to pay for captives. ${ }^{21}$

The same basic pattern holds for later years. A unique set of circumstances has left us with a remarkably detailed snapshot of the goods that were carried aboard Rio's slave ships in the middle of the nineteenth century. Under heavy British diplomatic pressure to stop their activities, Brazilian slave traders began employing U.S.-flagged vessels, which were not subject to search and seizure by the Royal Navy. Dismayed at the collusion between American shipowners and Brazilian slave traders, U.S. diplomats in Rio began gathering information. One of them, George W. Gordon, detailed the outbound cargoes of twenty-nine U.S. vessels that had been chartered or purchased by Brazilian merchants between 1843 and 1846 and can therefore be considered to be essentially Brazilian voyages. Because Gordon listed only quantities, it is not possible to give the relative values of the goods. For some categories, such as 'foreign goods,' it would be impossible to know exactly what the items were worth. In several other instances, he simply indicated that the quantity was large but could not say just how large. Still, it is possible to calculate the percentage of cargoes that included goods of a particular type. And on that score the obvious leader was cachaça (listed as 'rum'), which was carried aboard twenty-five of twenty-nine vessels. Thirteen carried

\footnotetext{
${ }^{21}$ Florentino, Em Costas Negras, pp. 131-135.
} 
sugar, though not all in significant amounts. Twelve of the twenty-nine carried 'foreign goods,' which surely included textiles but also likely encompassed other manufactures. Given the U.S. origin of these vessels, it is probable that some of the foreign goods were of American origin, but one of them is noted to have carried a cargo of goods from Liverpool. Gunpowder was another commonly carried item. Almost every ship carried powder, but the quantities listed indicate that some were using it in trade. Twelve vessels carried an average of $323 \mathrm{kegs}$ of powder, with four of them carrying over one thousand kegs. An assortment of other items filled out the trade cargoes for smaller numbers of ships. Five of them carried iron bars, one of which Gordon indicated carried a very large quantity. Another sailed with 'a large amount of specie' and very little else. ${ }^{22}$

\section{[INSERT TABLE 2 HERE]}

Gordon's list confirms the basic pattern up to this point. Plantation produce and its byproducts formed the foundation for all branches of the Brazilian trade. For Rio in the midnineteenth century, cane-derived spirits fulfilled the role that tobacco had for Bahia in the eighteenth century. But Rio's merchants could not make a living on cachaça alone. To that end, they did as their counterparts in Pernambuco and Bahia did and found ways to sort their cargoes with other goods. As we will see, the other New World traders were no different.

\footnotetext{
${ }^{22}$ On the use of the American flag by Brazilian vessels, see R. E. Conrad, World of Sorrow: The African Slave Trade to Brazil (Baton Rouge, LA, 1986), pp. 144-153; G. Horne, The Deepest South: The United States, Brazil, and the African Slave Trade (New York, 2007); D. Eltis, 'The U.S. Transatlantic Slave Trade, 16441867: An Assessment', Civil War History, liv (2008), pp. 371-377; D. Graden, Disease, Resistance, and Lies: The Demise of the Transatlantic Slave Trade to Brazil and Cuba (Baton Rouge, LA, 2014), pp. 25-39; L. Marques, The United States and the Transatlantic Slave Trade to the Americas, 1776-1867 (New Haven, 2016), pp. 139-184. As many scholars have noted, it can be impossible to determine the "flag" or nationality of voyages undertaken after abolition. But the fact that these U.S. vessels were chartered by Brazilian merchants strongly suggests that they were the organisers, with the Americans acting as willing auxiliaries.
} 


\section{[SINGLE LINE SPACE HERE]}

\section{V}

Barbados was another early entrant into the transatlantic slave trade, sending over three hundred vessels to Africa, while all of the other British islands together dispatched something more than two hundred. This trade operated almost continuously between 1675 and 1730 , with roughly half of all voyages embarking between 1700 and 1715 . The concentration in these years, which coincide with the War of the Spanish Succession, suggests Barbadians may have entered the trade to address a wartime reduction in slave shipments. In fact, however, the Barbados-based voyages (along with voyages organised in other colonies in the English Caribbean) were on the rise before the outbreak of hostilities in 1701. Another possible cause for Barbados's plunge into the trade was competition with other colonies, particularly Jamaica, for slaves, which was exacerbated by the Royal African Company's chronic inability to supply enough captives. Barbados had once consumed the lion's share of English captives; after about 1680 it had to settle for an ever-diminishing portion, even as its sugar economy continued to grow. Lastly, the termination of the Royal African Company's monopoly in 1698 and the institution of the Ten Percent system allowed Barbadians to continue their activities without fear of legal action. ${ }^{23}$

\section{[INSERT FIGURE 4 HERE]}

No studies of this trade exist, likely due to the scarcity of sources. Ownership data on the vessels, for example, is almost non-existent. What little information we have indicates that in the initial stages the colony's planter elite ran the trade. This makes a certain amount of sense, since sugar planters commanded a great deal of credit and capital and were the ones with the easiest access to the essential trade good, which was rum. A partnership of elite

\footnotetext{
${ }^{23}$ On Barbadian discontent with the Royal African Company, see K.G. Davies, The Royal African Company (1957; repr. New York, 1970), pp. 303-7.
} 
planters, for example, organised a voyage in about 1680. According to the Royal African Company factor at Bridgetown, the vessel was owned by Henry Drax, John Ross [Rous], Samuel Husbands, and Christopher and John Codrington. All of the men named came from the top echelon of the island's planter class. As the trade grew and matured, however, it is probable that the island's merchants, many with their many English connections, assumed the primary organizational role. ${ }^{24}$

However, rum was not the only good carried aboard Barbadian vessels. Port records for Bridgetown from 1698-1720, years that coincide with the peak period of the trade, survive for 115 of 189 vessels that embarked for Africa. Sixty-five percent of these vessels were recorded as carrying 'dry goods,' and at least five appear to have sailed with no rum at all, but rather with 'parcells' of 'English' or 'European' goods. Although the dry goods likely encompassed a variety of items, textiles were surely foremost among them. Most of these, moreover, appear to have been of British origin. Indeed, between 1700 and 1706, as this trade was gaining momentum, exports of British perpets and serges (both a type of woolen) to the British West Indies more than doubled, while direct exports of the same goods to Africa fell by almost half. One captain even advised the RAC to purchase its perpets in Barbados rather than in England. ${ }^{25}$ Several Barbadian vessels carrying perpets receive notice in the correspondence of the Royal African Company during the first decade of the eighteenth century. However, as suggested by those vessels listed as carrying European goods, Barbadian slavers likely carried other items in addition to English woolens, such as guns,

\footnotetext{
${ }^{24}$ TNA, CO 1/47, pg. 231. For the status of the owners, see R. S. Dunn, Sugar and Slaves: The Rise of the Planter Class in the English West Indies, 1624-1713 (Chapel Hill, NC, 1972), 57, 90, 95, 98. See also W. A. Pettigrew, Freedom's Debt: The Royal African Company and the Politics of the Atlantic Slave Trade, 16721752 (Chapel Hill, 2013), pp. 50-1.

${ }^{25}$ See Table XLIII in E. B. Schumpeter, English Overseas Trade Statistics, 1697-1808 (Oxford, 1960), p. 69. On the captain's advice, see BNA, T 70/5, fol. 1.
} 
metalware, and linens. The records do not permit an analysis of the relative value of these products, but we can gain some idea by calculating the proportion of the tonnage devoted to rum versus other goods. Those vessels carrying rum alone averaged about one hundred gallons (or one hogshead) per ton burthen. Vessels carrying dry goods carried about fiftyseven gallons for each ton burthen. These vessels were therefore presumably devoting almost half of their cargo space to goods other than rum. ${ }^{26}$

Another feature of the Barbados-based trade has bearing on the question of trade goods, which is that a large proportion of the vessels sailing from Bridgetown were not actually based there. According to port records, thirty-five percent of all vessels clearing for Africa 'belonged' to ports elsewhere, with London leading at 20 percent, followed by British North America at 9 percent and the other British Caribbean islands (along with Bermuda) at 6 percent. Surprisingly however, the London based vessels were no more likely to carry textiles to Africa than other vessels. In fact, with only 12 of 20 (or 60 percent) carrying dry goods, they were actually slightly below the average. This can be explained by the fact that four-fifths of them had arrived directly from Africa, indicating that they were employed in a kind of shuttle trade. It appears, then, that those textiles used in the slave trade arrived aboard ${ }^{26}$ This analysis is based on the shipping and customs data in TNA, CO 33/13, CO 33/14, and CO 33/15.
Because the amount of rum for each vessel was given in pipes, hogsheads, tierces, barrels, "anchors," and
rundlets, the ratio of rum to tons burthen must be taken as approximate. The following conversions were used to
calculate the number of gallons aboard each vessel: 1 pipe=120 gallons; 1 hogshead=110 gallons; 1 tierce=65
gallons; 1 barrel=30 gallons; 1 rundlet=18 gallons; 1 "anchor"/anker=10 gallons. For all but the anker, see J. J.
McCusker, 'Rum and the American Revolution: The Rum Trade and the Balance of Payments of the Thirteen
Continental Colonies, 1650-1775', Ph.D. diss., University of Pittsburgh, 1970, pp. 812, 818. For the anker, see OED Online. September 2016. Oxford University Press. http://0www.oed.com.serlib0.essex.ac.uk/view/Entry/7819?redirectedFrom=anker (accessed 17 November 2016). The few vessels for which it was not possible to calculate a gallons-to-tonnage ratio were not included. For perpets on the Gold Coast, see TNA, T 70/5, fols. 1, 8, 18. 
other vessels and were then re-sorted by Barbados merchants for the African trade. The participation of the North American-owned vessels is hardly surprising given the economic importance of the West Indian trade. Some, it appears, sailed from the North American mainland to Barbados laden with fish, produce, and lumber, which they swapped for rum and then embarked for Africa. It surely helps to explain why vessels embarking from Barbados, a net importer of foodstuffs, suddenly appeared on the African coast in 1707 peddling carrots, turnips, and radishes to the English forts. ${ }^{27}$

About three-fifths of the captives carried aboard British West Indian vessels embarked on the Gold Coast, with Senegambia and Sierra Leone together accounting for one fifth. The remainder were embarked mostly on the Bight of Benin. The prominence of the Gold Coast is not surprising. It was Africa's leading consumer of Anglo-American rum and would figure prominently in the North American trade. Sugarcane-derived spirits, as we have seen, were employed by all of the major New World traders. But as with all goods, African tastes dictated which varieties would be the most popular in a given time and place. The strong British presence on the Gold Coast, which dates to the latter half of the seventeenth century, was responsible for the popularity of rum in that region. ${ }^{28}$ But unlike their North American cousins, at the height of the trade West Indian vessels also purchased captives on the Bight of Benin, where French brandy was the preferred spirit. What allowed the West Indian traders to purchase captives in that region? Lacking manifests and similar documents we can only speculate. Surely the textiles carried aboard Barbadian vessels helped their efforts on the Bight of Benin. They may also have re-sorted their rum cargoes upon reaching the African coast, as the North Americans would. The Jamaican vessel Alexander Galley, for example,

\footnotetext{
${ }^{27}$ TNA, CO 33/13, CO 33/14, and CO 33/15. For the vegetables, see T 70/5.

${ }^{28}$ Akyeampong, Drink, Power, and Cultural Change, 21, 30; R. Shumway, The Fante and the Transatlantic Slave Trade (Rochester, NY,, 2011), p. 114. For the quotation, see TNA, T 70/5, pg. 10.
} 
apparently struck a deal with a 'Portuguez' for twenty-five rolls of Brazilian tobacco. It is reasonable to suppose that others did so as well. ${ }^{29}$

That the stretch of coast from Senegambia to Sierra Leone was the Barbadians' secondmost important area of activity is somewhat surprising. Unlike the Gold Coast, Angola, and the coastal polities on the Bight of Benin, the region had a Muslim presence of some significance, which would likely limit the demand for alcohol. As an English trader in the Gambia noted, 'The only Liquor to please a Mahometan is Sugar and Water'. In the early eighteenth century, however, the coastal Muslim population was still quite small; only in the second half of the century would Islam become a major force, and even then a majority of the population remained non-Muslim. In the Senegambia, the ceddo-type states, led by slaveraiding warlords, constituted an important market for alcohol. The Muslim population of Sierra Leone was still quite small in the early eighteenth century, which may explain why Barbadian vessels called there more frequently in the years 1726-1750. The rapacity and excesses of the ceddo (and similar) states, many nominally Muslim, contributed to the rise of an Islamic reform movement, unsuccessfully at first in the 1670 s but gaining traction in 1725/6 in the Futa Jallon and in 1776 in the Futa Toro. The Royal African Company seems to have understood that the market for rum in this region was poor. In the early eighteenth century, they shipped rum to the Rio Pongo in a deliberate attempt to get consumers to adopt it as the favored spirit. Despite their efforts, these regions could never absorb as much rum as the Gold Coast. ${ }^{30}$

\footnotetext{
${ }^{29}$ TNA, T 70/5, pg. 2

${ }^{30}$ F. Moore, Travels into the Inland Parts of Africa, Containing a Description of the Several Nations for the Space of Six Hundred Miles up the River Gambia (London, 1738), p. 77. On Sierra Leone, see D. E. Skinner, 'Mande Settlement and the Development of Islamic Institutions in Sierra Leone', International Journal of African Historical Studies, xi (1978), p. 34; D. E. Skinner, 'Islam in the Northern Hinterland and its Influence on the Development of the Sierra Leone Colony' in A. Jalloh and D. E. Skinner, ed., Islam and Trade in Sierra
} 
The British West Indian trade, of which Barbados was the leader, reached a peak of approximately ten voyages per year during the War of the Spanish Succession and declined sharply thereafter. Vessels continued to embark from the British Caribbean throughout the era of the legal trade, but sporadically and a much lower levels. Surely part of the reason for the decline was the increasing capacity of Bristol and Liverpool merchants to meet the demand for slaves in the British Caribbean with the final abolition of the Royal African Company's ten percent levy on private traders in 1712. At that point, it would have made more economic sense for Barbadians to focus on sugar planting and leave the slave trading to the better-supplied metropolitan merchants.

\section{[SINGLE LINE SPACE HERE]}

\section{VI}

The North American trade has been studied in depth, to the extent that its basic outline is quite clear. Merchants centered primarily in New England and secondarily in New York began dispatching vessels in the seventeenth century. North Americans were unique among New World slave traders in that their routes were mostly triangular rather bilateral - that is, rather than supplying New England with slave labor, they initially supplied the British

Leone (Trenton, NJ, 1997), pp. 1-4. A number of historians have argued that parts of the Senegambia and Sierra Leone share a common history and should be treated together. See W. Rodney, A History of the Upper Guinea Coast, 1545-1800 (Oxford, 1970); G. E. Brooks, Landlords and Strangers: Ecology and Trade in West Africa, 1000-1630 (Boulder, CO, 1994); B. Barry, Senegambia and the Atlantic Slave Trade (Cambridge: Cambridge University Press, 1998). On the jihads and reform movements, see W. Rodney, 'Jihad and Social Revolution in the Futa Djalon in the Eighteenth Century', Journal of the History Society of Nigeria, iv (1968), pp. 269-284; M. A. Gomez, Pragmatism in the Age of Jihad: The Precolonial State of Bundu (Cambridge, 1992); R. T. Ware III, The Walking Qur'an: Islamic Education and History in West Africa (Chapel Hill, NC, 2014), pp. 100-138; P. E. Lovejoy, Jihad in West Africa During the Age of Revolutions (Athens, OH, 2016), pp. 36-61. On the effort to introduce rum to the Rio Pongo, see TNA T 70/22, pg. 15. 
Caribbean and then, after U.S. independence, Cuba and South Carolina. ${ }^{31}$ The earliest voyages appear to have carried colonial produce first to Barbados, where they then acquired goods that were, in the words of one early trader, 'fitting for a voyage for Guiney'. For a time in the late seventeenth century, North Americans acquired captives from Indian Ocean pirates in exchange for alcohol and firearms. By turn of the eighteenth century, however, a rum trade similar to that of Barbados had become the norm. The earliest of these 'rum men' likely peddled West Indian spirits, but the New Englanders soon developed their own distilling industry, which consumed not only British, but also contraband molasses. Jay Coughtry has calculated that between $85-90$ percent of the value of the cargoes carried aboard eighteenth-century New England vessels consisted of rum, with tobacco as a secondary trade good. More than any of the other New World based traders, the North Americans succeeded at basing their slave trade on New World plantation produce. But like the Barbadians, North Americans found that the limited acceptance of rum in Africa restricted their activities primarily to the Gold Coast and secondarily to the Senegambia and Sierra Leone. ${ }^{32}$

\footnotetext{
${ }^{31}$ The New York-based slave trade of the colonial era is a partial exception, with about one-quarter of all vessels carrying captives back to New York. See P. Misevich, 'In Pursuit of Human Cargo: Philip Livingston and the Voyage of the Sloop Rhode Island', New York History, lxxxvi (2005), pp. 185-204.

32 J. Coughtry, The Notorious Triangle: Rhode Island and the African Slave Trade, 1700-1807 (Philadelphia, 1981); Eltis, "U.S. Transatlantic Slave Trade."; E. F. Crane, A Dependent People: Newport, Rhode Island in the Revolutionary Era (New York, 1985); L. Marques, 'Slave Trading in a New World: The Strategies of North American Slave Traders in the Age of Abolition', Journal of the Early Republic, xxxii (2012), pp. 87-113; Marques, The United States and the Transatlantic Slave Trade to the Americas; D. Richardson, 'Slavery, Trade, and Economic Growth in Eighteenth-Century New England', in Solow, ed., Slavery and the Rise of the Atlantic System; A. Jones, 'The Rhode Island Slave Trade: A Trading Advantage in Africa', Slavery and Abolition, ii (1981), pp. 227-244. The present discussion focuses on the legal era of the U.S.-based trade. Although U.S. vessels did trade after 1808, the principal American contribution was to the Brazilian and Cuban trades. See Eltis, 'U.S. Transatlantic Slave Trade', pp. 371-372.
} 


\section{[INSERT FIGURE 5 HERE]}

Nevertheless the North American trade, like all major New World-based slave trades, was not based solely on New World products. For while manifests and bills of lading clearly indicate that rum comprised upwards of 85 percent of the value of all trade goods, trade books--those accounts that recorded what was actually traded for captives-tell a more complex story. Rum unquestionably did finance most of the North Americans' purchases, especially on the Gold Coast. For five of the eleven voyages analyzed, rum accounted for at least 90 percent of the value of all trade goods exchanged for captives. But the other six suggest lower levels, mostly in the $70-80$ percent range, with a low of 46 percent. For vessels trading between the Gambia and Sierra Leone, where Islam was grew increasingly influential as the eighteenth century progressed, rum financed a correspondingly lower share of the captive purchases, ranging from 31 percent to 80 percent. $^{33}$

Aware of the problems associated with the rum trade-the frequent gluts and the overreliance on a single trade good--the North Americans employed a range of tactics to 'resort' their cargoes with other merchandise. These included trading for African textiles at the Cape Verde Islands before arriving at the mainland; trading with European vessels for Indian textiles and other goods; trading for gold in Africa to prior to arriving at their principal markets at Anomabu and Cape Coast; and sending longboats from the Gold Coast to the

\footnotetext{
${ }^{33}$ This discussion is based on an analysis of over a thousand individual transactions in fourteen trade books, all of which date to the period before 1776. Three of the vessels traded on both the Upper Guinea and Gold Coasts, so those transactions were analyzed separately for each region. From the Newport Historical Society, three unidentified vessels, 1733-36 (erroneously identified as the Greyhound in the catalogue). From the Slavery Collection at the New-York Historical Society: The Rhode Island (1749); Venus (1756); Marigold (1759); Royal Charlotte (1762); Active (1769); Othello (1769, 1770); and unidentified vessel (1774). From the Rhode Island Historical Society, The Sally (1767). From Brown University, The Sally (1764). And V. W. Crane, ed., A Rhode Island Slaver: The Trade Book of the Sloop Adventure, 1773-1774 (Providence, RI, 1922).
} 
Bight of Benin to purchase Bahian rolled tobacco. On the Gold Coast, about 53 percent of the transactions recorded in the trade books were made with rum alone; 47 percent involved some other good, including gold, textiles, tobacco, and metalware. Predictably, a much lower percentage of the transactions in Upper Guinea were made with rum alone, only 10 percent, with 90 percent of all transactions involving some other product. ${ }^{34}$

After the American Revolution, U.S. slavers saw an opportunity to reduce their reliance on rum, and they took it. This was made possible by two developments. First, political independence removed the North Americans from the British mercantilist system and opened their markets to continental imports. Second, American neutrality during the extended period of warfare that followed the French Revolution resulted in the United States becoming the preferred carrier for continental textile shippers like France and the Netherlands. The British vigorously contested the American position that 'free ships make free goods,' but that was not enough to prevent a wave of textile imports into the United States that fueled a re-export boom during the 1790s. Yankee slavers immediately recognised the significance for their activities and began to diversify their outbound cargoes with Indian cloth. An analysis of over 130 outbound manifests from the leading slave-trading ports of Newport and Providence, Rhode Island reveals that rum accounted for 92 percent of the value of all cargoes during the prewar years of 1790-93, but only 68 percent in during the wartime years of 1794-1801. One vessel embarked with $\$ 23,000$ in Indian textiles and other manufactures and $\$ 6,111$ in rum, which put the spirit's share of the total value at about 21 percent. $^{35}$

\footnotetext{
${ }^{34}$ See previous note.

${ }^{35}$ The analysis was based on an analysis of 132 Rhode Island ships' manifests from 1790-1801 in RG 36, Item No. 718, Outbound Foreign Manifests for Newport and Providence, French Spoliation Claims, National Archives, Washington, D.C.
} 
Textiles were especially prominent in South Carolina's slave rush of 1804-1807. This period saw an annual average of over forty slave ships sail from Charleston in what was largely a bilateral trade designed to feed the new cotton plantations of the lower South before the anticipated ban on slave importations in 1808. No dataset comparable to the Rhode Island manifests exists for South Carolina, but a great deal of anecdotal evidence suggests that this trade also involved large quantities of textiles. Most of those who organised the voyages that embarked from Charleston in those years, it appears, were not long-term residents but rather representatives of New England and British merchant houses, and those that were locally owned found it expedient to hire experienced Yankee or British supercargoes. This stands to reason since few native Charlestonians possessed the contacts and know-how necessary to run a successful foreign slave trade. This trade, moreover, drew heavily on Upper Guinea and West Central Africa, with the New Englanders employing their experience in the former and the British exploiting their contacts in both. Neither of these regions was particularly receptive to the rum trade, so it is not surprising to see evidence of other goods in the holds of Charleston ships. The city's newspapers, for example, carried numerous advertisements for not only rum, but such things as 'Indian PIECE GOODS, suitable for the African market'. Others offered a 'complete assortment of GOODS, Adapted for the leeward coast of Africa,' while still others advertised German steel knives, sickles, waffle irons, all 'for the African trade'. Manifests are scarce, but we do know that one British-owned vessel that sailed to Gorée carried $\$ 5,000$ in rum and $\$ 4,600$ in textiles. Another locally-owned vessel (one that employed a British supercargo to trade at Bonny, on the Bight of Biafra, suggestive once more of the importance of British networks in this trade) carried $\$ 2,746$ in rum and $\$ 7,336$ in textiles. Yet another vessel, owned by a Scottish 
merchant resident in Charleston, sailed for West Central Africa with 2 pipes of brandy, 18 puncheons of rum, 58 bales of 'India Goods,' and lesser quantities of 'Manchester Goods' . $^{36}$

Legal trading from North America ended on January 1, 1808. Illegal voyages departed from the United States in subsequent years, though hardly on the same scale as in Brazil and Cuba. But as David Eltis has pointed out, this raises one of the great counterfactual scenarios of the slave trade: what if the United States had not outlawed foreign slave trading? New England's textile re-exports of the 1790s and the Charleston slave rush of 1804-1807 suggest that improved access to textiles might have combined with its rising position in global maritime trade to make the U.S. into the world's leading slave-trading power. If large-scale trading had continued further into the nineteenth century, the Americans would have had been able to supply their vessels with domestically produced textiles. That did not happen, but it is worth noting that over the course of the nineteenth century rum declined in significance as a trade good. For 'legitimate' traders, rum constituted between half and twothirds of the value of their cargoes, a far cry from the 85-90 percent ratio of the previous century. And it is worth noting that the Mobile, Alabama-based Clotilda, the last known vessel to deliver captives to North America, carried Cuban aguardiente, 25 cases of dry goods, and \$20,000 in specie. Had the North Americans continued as major slave traders,

\footnotetext{
${ }^{36}$ No systematic study of this trade exists. For an overview, see J. A. McMillin, The Final Victims: The Foreign Slave Trade to North America, 1783-1810 (Columbia, SC, 2004), pp. 97-115; L. K. Ford, Deliver Us from Evil: The Slavery Question in the Old South (New York, 2009), pp. 81-111. Newspaper advertisements for trade goods are many. For those quoted here, see City Gazette, 29 October 1805, p. 3; ibid., 31 January 1807, p. 1; and ibid., 27 September 1806, p. 1. Invoice of merchandise aboard the Amedie, in Elizabeth Donnan, ed. Documents Illustrative of the History of the Slave Trade to America, 4 vols. (Washington, D. C., 1935), p. 4:544. Bill of Lading for the Africa, in ibid., 4:567.
} 
they would have operated more like one of the metropolitan powers rather than like the colonies they had been in the previous century. ${ }^{37}$

[SINGLE LINE SPACE HERE]

\section{VII}

Cuba was the last New World-based power to enter the slave trade. In contrast to the other American-based slavers, all of which began and perfected their trades well before abolition, Cuba did so only as its other suppliers (chiefly Britain and the United States) withdrew. Treaties and legal restrictions dating to the time of Columbus had prevented Spain and its colonies from engaging directly in the African trade. Then, starting in 1789 after persistent lobbying on the part of labor-hungry Cuban planters, Spain legalised the slave trade first for its own subjects and eventually for foreigners. The liberalization lured a number of Cuban Creoles into the business, but most of the market inevitably fell to more experienced and better connected British and North American traders. When participation became illegal for these two groups in 1807 and 1808, respectively, they largely withdrew from direct involvement. However, there is plenty of evidence to suggest that Anglo-Americans remained indirectly concerned in the trade, as suppliers of trade goods, as supercargoes aboard Spanish vessels, and as silent partners in slaving voyages. During the 1810s, Cuban and Spanish merchants and mariners served an apprenticeship of sorts, building networks and gaining experience. After that the Anglo-Americans receded in significance (though it

\footnotetext{
${ }^{37}$ Eltis, 'U.S. Transatlantic Slave Trade', pp. 377-378; G. Brooks, Yankee Traders, Old Coasters and African Middlemen: A History of American Legitimate Trade with West Africa in the Nineteenth Century (Brookline, MA, 1970), pp. 89-90; S. A. Diouf, Dreams of Africa in Alabama: The Slave Ship Clotilda and the Story of the Last Africans Brought to America (New York, 2007), p. 25.
} 
should be noted that Portuguese and Brazilian merchants and mariners increased their involvement). ${ }^{38}$

\section{[INSERT FIGURE 6 HERE]}

All trading carried on after 1820 - which is to say vast majority of Cuban trading--was carried on illegally, which means that there are few documents with which to reconstruct the voyage organization. What is clear, however, is that the Cuban trade of the post-1820 period was carried on by sophisticated, multinational, clandestine networks, which Michael Zeuske has termed the 'Hidden Atlantic'. Anchored by several extended-family syndicates in Cuba, these networks encompassed the whole of the Atlantic rim, from Britain, to the Gallinas, to Angola, and from Brazil, and to New York. They employed sophisticated financial

\footnotetext{
${ }^{38}$ For an overview of the legalization of the Cuban slave trade, see D. R. Murray, Odious Commerce: Britain, Spain and the Abolition of the Cuban Slave Trade (Cambridge, 1980), pp. 1-21. For an example of collaboration by U.S. and Cuban slavers soon after abolition, see Howard v. Wales, RG 21, U.S. Circuit Court for Massachusetts, Case Files, Box 21, May 1813, National Archives, Boston. No comprehensive scholarly treatment of the Cuba-based slave trade currently exists, though the work of Jorge Felipe Gonzalez promises to help fill the gap. Most studies focus either on the legal/diplomatic aspects of the trade or on the arrival of Africans in Cuba. Works that address the organization of the trade in a substantial way include Franco, Comercio Clandestino de Esclavos; Eltis, Economic Growth; L. Marques, 'A Participação Norte-Americana no Tráfico Transatlântico de Escravos para os Estados Unidos, Cuba, e Brasil', Historia: Questões \& Debates, lii (2010), pp. 87-113; Graden, Disease, Resistance, and Lies; Thomas, Slave Trade; M. Moreno Fraginals, El Ingenio: Complejo Económico Social Cubano del Azúcar (Barcelona, 2001); Zeuske, Amistad; S. Johnson, 'The Rise and Fall of Creole Participation in the Cuban Slave Trade, 1789-1796', Cuban Studies, xxx (2000), pp 52-75; J. M. Delgado Ribas, 'The Slave Trade in the Spanish Empire (1501-1808): The Shift from Periphery to Center', pp. 13-42, in J. M. Fradera and C. Schmidt-Nowara, ed., Slavery and Antislavery in Spain's Atlantic Empire (New York, 2013); M. Rodrigo y Alharilla, 'Spanish Merchants and the Slave Trade: From Legality to Illegality, 1814-1870', pp. 176-199, in ibid.
} 
techniques, enjoyed political protection, and assembled a wide variety of trade goods from all over the world. ${ }^{39}$

Cuban slavers drew on a geographically broad selection of African markets, with no one of them responsible for even one-third of the total. The Bight of Biafra led all others at 30 percent, followed by West Central Africa at 23 percent, the Bight of Benin at 19 percent, Upper Guinea at 15 percent, and Southeast Africa at 12 percent. The Gold Coast was the only major historic slave-trading region not substantially involved. This remarkably well distributed trade resulted from a variety of factors. The Anglo-American apprenticeship provided an early entrée into the markets of Upper Guinea, while collaboration with the Luso-Brazilians gave them access to networks on the Bight of Benin, in the Kongo-Angola region, and in Southeast Africa. The Cuban prominence in the Bight of Biafra was likely a legacy of the British networks from the previous century.

To trade in so many regions, with their differing consumer tastes, Cubans needed access to an unusually wide array of goods. Aguardiente, for example, the Cuban answer to cachaça, could not form the cornerstone of the slave trade in West Africa during an age of Muslim holy war. The Bight of Benin, which was the source of about 16 percent of all Africans carried to the island after 1800 , was wracked by a series of conflicts beginning with the jihad inaugurated by 'Uthman dan Fodio in 1804, which resulted in the creation of the Sokoto Caliphate, a state whose dominance of the Central Sudan would far outlast the transatlantic slave trade. Elsewhere in West Africa during in the nineteenth century, the Futa Jallon was extending its influence toward the coast. Theophilus Conneau, a French-Italian slave trader on the Rio Pongo, once refused a Cuban commission because the vessel was 'only loaded with rum'. And on the Bight of Biafra, the single-most important source of

\footnotetext{
${ }^{39}$ Zeuske, Amistad, pp. 95-121; Eltis, Economic Growth, pp. 145-150; Franco, Comercio Clandestino De Esclavos, pp. 219-256; Moreno Fraginals, El Ingenio, pp. 213-239.
} 
captives for Cuban traders, appears to have imported no alcohol at all during the era of the slave trade, so trading there required access to alternate goods. Nor could Cuban tobacco ever do much more than augment a trade good assortment. ${ }^{40}$

As it happens, Cuban merchants did have access to a wide variety of goods, as well as specie from the former Spanish mainland colonies. Sales records for captured Cuban vessels at Sierra Leone reveal that they carried particularly well-sorted outbound cargoes. Tobacco and aguardiente figured significantly in the Cuban assortment, but textiles were the most valuable trade good by a margin of about 3:2. The provenance of the textiles cannot be reliably inferred from the sales record. Many of them carry Indian names, so it is possible that at least some portion came from Asia. However, since most Cuban slave trading took place after the decline of India as a textile exporting nation and during an era of fullyindustrialised capitalism in Britain and the United States, it is probable that most of the textiles were imitations of Indian weaves and prints produced in factories. Britain and the U.S., moreover, were both in the process of flooding Cuba with cheap manufactures, which would have ensured a steady supply of goods on credit. Cuban slave trading, then, had a

\footnotetext{
${ }^{40}$ T. Conneau, A Slaver's Logbook: The Original 1853 Manuscript by Theophilus Conneau (London, 1976), p. 107; D. Northrup, Trade without Rulers: Pre-Colonial Economic Development in South-Eastern Nigeria (Oxford, 1978), p. 166. On jihad in this era, and on its impact on the slave trade, see Lovejoy, Jihad in West Africa during the Age of Revolutions, 68-87; M. Barcia, West African Warfare in Bahia and Cuba: Soldier Slaves in the Atlantic World, 1807-1844 (Oxford, 2014), pp. 22-43. Although they do not address the question of alcohol, Jennifer Lofkranz and Paul Lovejoy have argued that Muslim merchants in West Africa adhered to Islamic commercial law. See J. Lofkranz and P. E. Lovejoy, 'Maintaining Network Boundaries: Islamic Law and Commerce from Sahara to Guinea Shores', Slavery and Abolition, xxvi (2015), pp. 211-232.
} 
strong industrial dimension that was consistent with the distinctly 'modern' qualities of its plantation sector. $^{41}$

Cuban traders also took advantage of their proximity to the neighboring islands to acquire manufactured for exchange. Theophilus Conneau sailed from Santiago de Cuba to Jamaica in order to purchase 'a suitable cargo of English merchandises for the [African] Coast,' returned to Cuba, and then embarked for Africa. In the case of the Golondrina, seized off Loango in 1836, a British firm in Jamaica contributed to an outbound cargo consisting of powder, muskets, knives, aguardiente, looking-glasses, padlocks, beads, razors, flints, cutlasses, and iron bars. The Danish island of St. Thomas was another favorite source for European manufactures. The Negrito, which sailed from Havana in 1832, stopped at St. Thomas for a cargo of cotton goods, aguardiente (rum), and gunpowder before embarking for Ouidah. Over the next few decades many other vessels would do the same. ${ }^{42}$

[INSERT FIGURE 7 HERE]

[SINGLE LINE SPACE HERE]

\section{VIII}

Three major conclusions can be drawn from the preceding discussion. The first of these concerns the ability of New World traders to turn agricultural produce and byproducts into marketable trade goods. All of the American slave-trading powers solved the problem of trade goods, with cane-based distilled spirits serving as a cornerstone of each of the four

\footnotetext{
${ }^{41}$ For the trade goods, see Figure 6, which is based on TNA FO 84/9, FO 84/15, FO 84/50, FO 84/78, FO $84 / 193$.

${ }^{42}$ Conneau, A Slaver's Logbook, 188. Correspondence with British Coms. at Sierra Leone, Havana, Rio de Janeiro and Surinam on Slave Trade: 1836 (Class A) P.P. (001) lviv.1 pg. 67-8, 69-70, 79-80, 95-6; Correspondence with British Ministers and Agents in Foreign Countries, and with Foreign Ministers in England, on Slave Trade, 1851-52 (Class B). House of Commons Papers. P.P. (0.3) ciii pt.ii.1 pg. 917.
} 
trades. Tobacco ran a distant second, important to North America, Cuba, and Brazil, but only in the case of Bahia was it truly indispensable. Traders based on the American mainland diversified their wares by drawing on the produce of their agricultural and ranching hinterlands, an option not available to island-based merchants. For Brazilians, this meant occasionally carrying horses to Angola and other destinations, while for the North Americans, it meant peddling onions, lumber, locally-produced metalware, and spermaceti candles. However, as successful as these trade goods were, all merchants recognised the limitations of trading local produce alone and all sought to maximise their purchasing power by acquiring manufactured goods. For Barbados and Cuba, this usually meant embarking for Africa with the goods already onboard (though sometimes they were taken on at neighboring islands). For the North Americans, at least before the re-export boom of the $1790 \mathrm{~s}$, it generally meant acquiring the goods in a round of preliminary trades with European and African merchants on the African coast. Brazilian vessels combined both approaches, sometimes embarking with re-exported textiles but just as often leaving the assortment to Portuguese merchants based in Luanda and elsewhere.

Of the four, the North Americans relied the most on produce (or byproducts thereof), with rum accounting for approximately 90 percent of the value of their outbound cargoes. This is surprising given the fact that North America, and New England especially, had long imported many of the same sorts of goods-textiles, metalware--that were in use for the slave trade. But the strong domestic market for these goods in North America surely helps to explain why Yankee merchants did not re-export them to Africa, as Brazilian, Barbadian, and Cuban traders did. That only happened near the end of the slave trade in the 1790 s, when the U.S. market was suddenly flooded with continental goods. The Bahian tobacco trade to the Bight of Benin probably ran second-future quantitative studies may tell. But both the carregaçoes of the seventeenth and eighteenth centuries and the records of the cargoes 
auctioned off at Sierra Leone indicate that Bahian cargoes were more assorted than previously believed. Barbados probably ran third, with a significant minority of vessels lading rum alone. Still, almost two thirds of Barbadian vessels carried manufactures, and in significant quantities. Cuban and the other Brazilian vessels, especially those from Rio, appear either to have carried larger amounts of textiles, acquired them after embarking, or took advantage of diffuse networks to recombine their plantation goods. Both of these trades flourished in the nineteenth century and benefited from the availability of low-cost British (and to a much lesser extent, U.S.) textiles.

Secondly, the success of New World-based slave trading complicates the usual distinctions between metropolis and colony, and between core and periphery. ${ }^{43}$ New World slave traders blurred this boundary by engaging in what is normally considered a metropolitan endeavor. And they did so not, as is often supposed, by trading solely on the basis of on their own agricultural produce, but by carrying many of the very same goods as metropolitan traders. That said, it is not the case that these colonies had completely escaped the metropolitan orbit. The political independence of the United States gave New England merchants access to imported goods, but the U.S. did not become capable of exporting large quantities of its own textiles until well after abolition. The relocation of the Portuguese court to Rio in 1807 produced a similar result, in that it opened Brazil to British manufactures which could be re-exported, but that tended to perpetuate economic dependence, not circumvent it. The New World slave-trading colonies succeeded not by becoming more metropolitan but by working within existing imperial networks. Brazilian-Portuguese

\footnotetext{
${ }^{43}$ Both formulations have recently come in for reexamination, the former most notably among Brazilian scholars of the South Atlantic and the latter among historians of Asia. See for example Alencastro, $O$ Trato dos Viventes, pp. 9-10 and passim; K. Pomeranz, The Great Divergence: China, Europe, and the Making of the World Economy (Princeton, NJ, 2000).
} 
merchants are the prime example, aided by the diffuse structure of their mercantile empire, and it is quite clear that Barbadian traders did so as well, though the British Empire was clearly less diffuse and more centered on London. North Americans needed to violate imperial restrictions in order to secure the molasses needed for distilling, but they worked within British networks on the African coast even after independence. Cuba was the outlier on that score, for while many traders worked within Spanish (or Catalan) networks, the illegal nature of most trade led merchants to create multi-national (or even anational) criminal networks. Indeed, much of the Cuban trade was organised by a polyglot confederation of Creoles, Castilians, Catalans, Portuguese, Brazilians, Britons, Frenchmen, and North Americans.

Finally and perhaps most importantly, the present comparison underscores the global nature of the transatlantic slave trade. Historians have long been aware that a large proportion of the goods that Europeans exchanged for captives originated in Asia, but they have been much slower to explore the implications. Several promising studies of Indian textiles in the slave trade are now in the works, and they are sorely needed. Somewhat more literature exists on African consumption of textiles and other goods, but much remains unknown. The prominence of manufactured goods for New World-based traders highlights the need for historians of the transatlantic slave trade to pay much more attention to Asia. Embracing the task will force historians beyond the familiar bounds of Atlantic history and in the direction of a truly global history. ${ }^{44}$

\footnotetext{
${ }^{44}$ The theme has only recently begun to gain traction. See for example K. Nimako and G. Willemsen, The Dutch Atlantic: Slavery, Abolition and Emancipation (London, 2011), pp. 52-60, 185-6.
} 
